\title{
Four days a week and less on appropriate antiviral combinations provided long-term optimal control over HIV-1 in 92 patients
}

\author{
Jacques Leibowitch*, Dominique Mathez, Pierre de Truchis, Damien Ledu, Jean Claude melchior, \\ Guislaine Carcelain, Jacques Izopet, John David, Christian Perronne
}

From International Symposium HIV and Emerging Infectious Diseases 2014

Marseille, France. 21-23 May 2014

\section{Patients and treatments}

92 volunteer patients on optimally suppressive antiviral combinations for 5 months or more consented to step wisely reduce their weekly treatment from 7 to 5 to 4 days/wk, or directly from 7 to $4 \mathrm{~d} /$ wk after bi-monthly checks on HIV plasma levels at $<50$ copies. Weekly treatment was further reduced to 3,2 , and $1 \mathrm{~d} / \mathrm{wk}$ for respectively 72, 59 and 12 pts. Antiviral combinations included : one integrase inhibitor-base +2 or 3 NRTIs, or 1 NNRTI and 1 PI (for $4 \mathrm{~d} /$ wk regimens, (Rx); standard triple combinations of 1 PI or 1 NNRTI + 2 NRTIs (for 4, 3 , $2 \mathrm{~d} / \mathrm{wk} \mathrm{Rx}$ ); novel quadruple antiviral compositions of 1 NNRTI + 3 NRTIs (for $4,3,2,1$ $\mathrm{d} /$ wk Rx).

\section{Results}

Intermittent treatment fully controlled patients' HIV over 20592 treatment-weeks. Of the 92 patients at entry, 88, 66 and 51 had sustained 52 weeks with 3,4 or 5 weekly days off-treatment periods respectively. Lymphocyte surface activation markers or cell-bound HIV DNA levels remained stable or declined further; CD4/ CD8 ratios rose to $\geq 1$ in $37 \%$ of patients - versus $7 \%$ patients before discontinuous treatment.

Viral failures: 13 viral escapes (plasma HIV RNA $>50$ copies 4 weeks apart; overall failures 3.3 per 100 discontinuous treatment-years) were countered by prompt readjustments with 7 day-a-week effective combinations. In retrospect 10 failures were ascribable to physician's or patients' errors or blunders: base-drug prescribed at sub $(1 / 2)$ optimal daily dosage (3 pts); overlooked archival resistant HIVs from antecedent treatment failures (5 pts);

Raymond Poincaré Hospital, Infectiology Department, Garches, France acute erratic observance ( 2 pts); HIV inadvertently resurged while on a 5 day off (2 pts) or 6 days offtreatment period, all 3 under one quadruple combination, setting the antiviral power limit of the ultra-short treatment modality with that combination at 1.4 failures per 100 proper treatment-years.

\section{Conclusion}

discontinuous maintenance therapy in 92 patients on ARV 4 days a week and less over an average 219 treatment-weeks (median 131) offered 40 to $85 \%$ medicinal cuts.

Published: 23 May 2014

\section{doi:10.1186/1471-2334-14-S2-O5}

Cite this article as: Leibowitch et al:: Four days a week and less on appropriate antiviral combinations provided long-term optimal control over HIV-1 in 92 patients. BMC Infectious Diseases 2014 14(Suppl 2):O5.

Submit your next manuscript to BioMed Central and take full advantage of:

- Convenient online submission

- Thorough peer review

- No space constraints or color figure charges

- Immediate publication on acceptance

- Inclusion in PubMed, CAS, Scopus and Google Scholar

- Research which is freely available for redistribution 